\title{
Roger Bates Memorial Tribute
}

\author{
Joseph A. Rard • Earle Waghorne
}

Published online: 26 August 2009

(C) Springer Science+Business Media, LLC 2009

The name Roger Bates is immediately recognized by everyone who has measured the $\mathrm{pH}$ of a solution, because he and his colleagues developed many of the techniques now used for precise $\mathrm{pH}$ measurements along with the methodology and NBS/NIST standards still widely used for the calibration of $\mathrm{pH}$ meters.

Roger Bates passed away in 2007 and this issue is dedicated to honoring this great scientist. The editors thank Arthur Covington (Emeritus Professor, University of Newcastle upon Tyne) for serving as Guest Editor for this special issue and both he and Donald A. Palmer (retired Editor-in-Chief, now Consulting Editor for this Journal) for their work in bringing about this issue, including helping with editing of the papers.

J.A. Rard ( $\varangle)$

Livermore, CA 94550, USA

e-mail: Solution_chemistry2@comcast.net

E. Waghorne

UCD School of Chemistry and Chemical Biology, University College Dublin, Belfield, Dublin 4,

Ireland

e-mail: earle.waghorne@ucd.ie 